\title{
APLIKASI VISUAL DNA MANUSIA MENGGUNAKAN AUGMENTED REALITY SEBAGAI SARANA MEDIA PEMBELAJARAN
}

\author{
Lalu Heru Adiatma', Yosep Agus Pranoto², Abdul Wahid ${ }^{3}$ \\ Program Studi Teknik Informatika S1, Fakultas Teknologi Industri \\ Institut Teknologi Nasional Malang, Jalan Raya Karanglo km 2 Malang, Indonesia \\ laluheruadiatma@gmail.com
}

\begin{abstract}
ABSTRAK
DNA (Deoxyribose Nucleic Acid) adalah molekul dalm tubuh manusia dalam mencari informasi hubungan antara barang bukti medis dengan pelaku, ilmu pengetahuan ini berkembang pesat digunakan sesudah tahun 90 an. Memanfaatkan sampel DNA memiliki nilai lebih dalam identifikasi sebuah kasus.

Dengan menghadapi kemjuan teknologi, belajar atau mengenal struktur DNA manusia tidaklah sulit.Bagi yang masih asing mengetahui tentang bentuk struktur DNA manusia denagn aplikasi edukasi interaktif berbasis android. Dimana aplikasi tersebut akan mempermudah kita belajar mengenai bentuk struktur DNA manusia yang diterapkan menggunakan teknologi Augmented Reality.

Oleh karena itu penulis bermaksud membuat aplikasi visual DNA Manusia menggunakan Augmented Reality adalah sebagai sarana belajar dan salah satu cara untuk mengenal bentuk struktur DNA manusia secara efisien dan efektif. Tapi perlu di ketahui bahwa belajar yang baik adalah dengan mendatangi sumber ilmu itu sendiri secara langsung.
\end{abstract}

Kata Kunci : Struktur DNA manusia, Augmented Reality, android.

\section{PENDAHULUAN}

\subsection{Latar Belakang}

Forensik molekuler adalah salah satu cabang ilmu kedokteran dengan memanfaatkan perkembangan teknologi biologi molekuler dalam pemecahan berbagai kasus forensik seperti pelacakan pelaku pembunuhan, pencarian orang hilang, dan pembunuhan ibu terhadap anak sendiri. Dalam penggunakan DNA (Deoxyribose Nucleic Acid) adalah salah satu cara dalam mencari informasi hubungan antara barang bukti medis dengan pelaku, langkah ini berkembang pesat digunakan setelah era 90an. Memanfaatkan sampel DNA memiliki nilai lebih dalam identifikasi sebuah kasus.[1]

Dengan menghadapi perkembangan teknologi saat ini, belajar atau mengenal struktur DNA manusia tidaklah sulit dilakukan. Telah banyak cara yang dilakukan oleh peneliti terdahulu untuk menumbuhkan minat belajar. Salah satunya yaitu dengan semua masyarakat umum yang belum mengetahui bentuk struktur DNA manusia denagn aplikasi edukasi interaktif berbasis android. Dimana aplikasi tersebut akan mempermudah kita belajar mengenai bentuk struktur DNA manusia yang diterapkan menggunakan teknologi augmented reality.

Oleh karena itu penulis bermaksud membuat aplikasi visual DNA Manusia menggunakan Augmented Reality adalah sebagai sarana belajar dan salah satu cara untuk mengenal bentuk struktur DNA manusia secara efisien dan efektif.

\subsection{Rumusan Masalah}

Berdasarkan permasalahan yang sudah dipaparkan pada latar belakang diatas, maka dapat dirumuskan sebagai berikut:
1. Bagaimana merancang dan mengimplementasikan Aplikasi Visual DNA Manusia Menggunakan Augmented Reality sebagai sarana media pembelajaran berbasis android.

2. Bagaimana mengimplementasikan Marker Based Tracking pada augmented reality untuk menyampaikan bentuk struktur molekul DNA (Deoxyribo Nucleic Acid) manusia pada teknologi augmented reality.

3. Bagaimana modeling objek 3D struktur molekul DNA manusia menggunakan software Blender.

4. Bagaimana mengimplementasikan informasi berupa suara, teks, dan tombol pada aplikasi visual DNA manusia dengan teknologi augmented reality menggunakan software Unity.

\subsection{Batasan Masalah}

Agar permasalahan yang dimaksud tidak meluas, lebih terarah dan mudah dipahami maka diperlukan suatu batasan masalah dalam penelitian ini, yaitu :

1. Aplikasi ini hanya berbasis android.

2. Aplikasi ini di buat dengan software Blender 2.80/2.78c, Unity3d 2017.4.29f1, Vuforia, Android sdk dan Android jdk.

3. Output berupa objek 3D struktur DNA (Deoxyribo Nucleic Acid) Manusia

4. Marker dapat di deteksi apabila tidak terhalang oleh sinar matahari.

5. Aplikasi ini hanya berbahasa Indonesia.

6. Target pengguna yaitu masyarakat umum.

7. Sumber data dari buku "Biologi Molekular" oleh Ir.Triwibowo Yuwono, Ph.D 
8. Pengenalan bentuk struktur $D N A$ manusia secara umumnya.

\subsection{Tujuan}

Terdapat beberapa tujuan dari pembuatan aplikasi ini sebagai berikut :

1 Mempermudah pengguna untuk mengetahui bentuk visual DNA manusia dari sebuah aplikasi.

2 Salah satu cara untuk menumbuhkan minat belajar masyarakat umum dengan menerapkan teknologi Augmented Reality pada sebuah kartu atau kertas.

3 Pengenalan Struktur DNA manusia melalui teknologi Augmented Reality.

4 Mengimplementasikan teknologi augmented reality sebagai salah satu sarana teknologi tanpa harus membeli buku yang berkaitan struktur DNA manusia dalam bentuk objek 3D berbasis android.

\subsection{Manfaat}

Terdapat beberapa manfaat dari pembuatan aplikasi ini sebagai berikut :

1 Mengajak masyarakat umum untuk mengenal bentuk Struktur DNA manusia.

2 Dapat membantu masyarakat umumnya untuk mengetahui informasi dari bentuk struktur DNA Manusia.

3 Untuk penulis, membantu memahami fungsi teknologi augmented reality menggunakan marker berbasis android dalam pembuatan media pembelajaran tentang struktur DNA manusia.

\section{TINJAUN PUSTAKA}

\subsection{Penelitihan Terkait}

Haryanto, dkk pada tahun 2017 Dalam penelitiannya membahas tentang teknologi Augmented Reality, dengan adanya teknologi tersebut dapat dimanfaatkan sebagai media pembelajaran berbasis android. Objek dibuat dalam bentuk model tiga dimensi dilengkapi dengan animasi pada objeknya seakan dalam dunia maya objek yang dibuat menyatu dengan dunia nyata dengan media kamera pada smartphone. Sehingga aplikasi dapat diimpelentasikan dengan beberapa software pendukung dalam meneyelesaikan penelitianya yiatu game engine menggunakan software unity, modelling objek menggunakan software blender dan tools Vuforia untuk media penyimpanan database. Hasil akhir berupa buku katalog yang berisikan marker dan aplikasi ini ditunjukan kepada siswa sekolah menengah atas (SMA) yaitu tentang pemeblajaran betuk sel. [2]

Kristian, dkk pada tahun 2016. Dalam penelitiannya membahas bisnis properti, untuk masa sekarang membahas tentang kemajuan teknologi para wirausahawan telah menanamkan teknologi dalam media promosi produknya yaitu dengan menerapkan teknologi Augmented Reality pada objek yang kan dikomersialkan kepada masyarakat karena para wirausahawan melihat dari sundut pandang yang berbeda agar calon pembeli puas melihat barang yang akan dibelinya. Oleh karena itu untuk mengimplentasikan ide tersebut peneliti akan membuat sebuah aplikasi visual model rumah menggunakan teknologi Augmented Reality dalam bentuk model 3 dimensi untuk melihat maket rumah sehingga calon pembeli bisa dengan leluasa melihat rumah impian yang akan dibelinya. Pembuatan aplikasi ini menggunakan software Unity sebagai geme engine bahasa pemrograman yang digunakan C\#. Sedangkan untuk pembuatan modelling rumah menggunakan software Blender yang menghasilkan objek 3 dimensi. [3]

Dedy Irawan, dkk pada tahun 2015. Dalam penelitiannya membahas Pemrograman yaitu salah satu pelajaran yang dianggap sulit oleh para murid di SMK, sehingga banyak siswa yang mengalami kesulitan dan malas untuk mempelajarinya, hal ini disebabkan pada pemrograman dibutuhkan banyak sekali perintah-perintah yang harus dituliskan, membuat para murid menjadi kesulitan. Dengan menggunakan greenfoot, pembuatan program dalam hal ini pembuatan game dapat dilakukan dengan mudah, karena pada pemrograman ini hanya dibutuhkan sedikit sekali perintah-perintah yang ditambahkan untuk membuat sebuah game, sehingga para murid akan dengan lebih mudah dapat memahami pemrograman dengan lebih baik. [4]

Eka Apriyani, dkk pada tahun yang sama. Dalam penelitiannya membahas tentang hewan purbakala yang diperkenalkan memlalui media pembelajran sejarah dimasa sekolah dan divisualisasikan dalambentuk tulisan dan gambar. Dalam mengimplentasikan pengenalan hewan purbakala peniliti memiliki rencana yaitu dengan menerapkan teknologi Augmented Reality sebagai media pembelajaran yang akan digukan pada anak sekolah agar tidak lupa dengan sejarah terdahulu. Augmented reality dapat menjadi sebuah alat peraga virtualisasi hewan purbakala dalam bentuk tiga dimensi. Aplikasi augmented reality ini sebagai media pengenalan hewan purbakala kepada anakanak usia 13 sampai 18 tahun secara virtual menggunakan perangkat smartphone agar proses pengenalan hewan purbakala dapat menjadi lebih menarik. Virtualisasi Alat Peraga Pengenalan Hewan Purbakala menggunakan augmented reality dapat menampilkan animasi hewan purbakala dalam bentuk 3D. Pengguna menjalankan aplikasi kemudian aplikasi akan melakukan pelacakan marker, setelah marker dikenali sesuai data acuan yang terdapat didalam sistem aplikasi. Pembuatan aplikasi ini menggunakan software Unity sebagai geme engine bahasa pemrograman yang digunakan C\#. Sedangkan untuk pembuatan modelling hewan menggunakan software Blender yang menghasilkan objek 3 dimensi. [5]

Daud Pramono, pada tahun 2018 Dalam penelitiannya membahas tentang jenis hewan 
berdasarkan sumber makanannya hanya dapat dipelajari secara teori. Hewan berdasarkan jenis makanannya dibagi menjadi 3 yaitu hewan karnivora, herbivora dan omnivora. Jenis hewan herbivora dikenal sebagai hewan pemakan tumbuhan dan banyak dijumpai di kehidupan. Aplikasi Augmented Reality ini sebagai media pembelajaran pengenalan jenis hewan herbivora kepada kalangan pelajar khusus nya tingkat sekolah dasar menggunakan perangkat smartphone agar proses pengenalan jenis hewan herbivora lebih menarik. Aplikasi ini dapat menampilkan objek animasi hewan herbivora dalam bentuk $3 \mathrm{~d}$ beserta suara hewan, menampilkan tata cara penggunaan aplikasi secara virtual menggunakan aplikasi yang berbasis Augmented Reality. [6]

\subsection{Augmented Reality}

Augmented Reality (AR) merupakan metode menggabungkan antara dunia maya dengan dunia nyata dalam teknologi ini memungkinkan sebuah objek pada dunia maya akan menyatu degan lingkungan dunia nyata dengan memnfaatkan tools Vuforia selaku wadah database dan unity adalah sebagai game engine dari sebuah aplikasi berbasis android dengan memnfaatkan teknologi Augmented Reality. [7]

Dari adanya teknologi augmented reality yaitu dengan mengambil dunia nyata sebagai layer dasar dengan menyatukan beberapa teknologi virtual dan menambahkan data konstektual yaitu suara, gambar, video agar pemahaman manusia sebagai penggunanya menjadi semakin jelas.

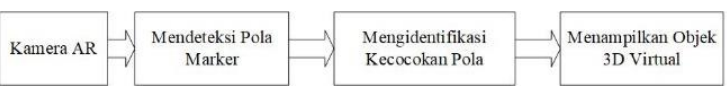

Gambar 2.1 Cara kerja Augmented Reality

\subsection{Vuforia}

Vuforia adalah library Augmented Reality Software Development Kit (SDK) yang digunakan sebagai pendukung adanya augmented reality pada android. Vuforia menganalisa gambar dengan menggunakan pendeteksi marker dan menghasilkan informasi 3D dari marker yang sudah dideteksi. SDK ini menggunakan teknologi computer vision untuk mengenali dan melacak gambar planar (Gambar Target) dan objek 3D sederhana, seperti kotak, secara real-time. Kemampuan vuforia yang dapat merubah kertas dengan latar kosong menjadi tampilan dengan grafis 3D yang menarik, karena adanya teknologi augmented reality. Dengan vuforia, developer dapat memaksimalkan kemampuan teknologi augmented reality untuk menciptakan konten seperti, aplikasi, game, iklan dan presentasi. Vuforia menyediakan Antarmuka Application Programming (API) di C++, Java, Objective-C, dan bahasa Net.[8]

\subsection{Image Marker}

Image Target adalah gambar yang bisa dilacak dan dideteksi oleh Vuforia SDK. Vuforia SDK mengaplikasikan algoritma khusus untuk mendeteksi dan melacak fitur yang secara natural ditemukan didalam sebuah gambar.

Gambar yang akan digunakan sebagai image target harus memiliki beberapa kriteria pembuatan image target yaitu:

1. Memiliki format 8 atau 16-bit dan JPG atau PNG.

2. Gambar berformat JPG harus memiliki warna RGB atau grayscale

3. Memiliki resolusi minimal 320 pixel.

4. Memiliki ukuran maksimal $2 \mathrm{MB}$.

5. Gambar tidak memiliki pola yang berulang.

Setelah diunggah, secara otomatis gambar akan mendapat implementasi algoritma yang dibuat khusus oleh vuforia sehingga fitur-fitur bisa terlihat dengan jelas. [8]

\subsection{Unity}

Unity Technologis dibangun pada tahun 2004 oleh David Helgon, Nicholas Francis dan Joachim Ante. Game Engine ini dibangun atas dasar kepedulian mereka terhadap indie develover yang tidak bisa membeli game engine karena terlalu mahal. Ditahun 2009, Unity diluncurkan secara gratis dan pada bulan April 2012, Unity mencapai popularitas tinggi dengan lebih dari 1 juta develover terdaftar seluruh dunia. Sebagai pelopor game engine murah secara default unity telah diatur untuk pembuat game bergenre First Person Shooting (FPS), namun unity juga bias digunakan untuk membuat game bergenre Role Playing Game (RPG) dan Real Time Strategi (RTS) Selain itu unity merupakan game engine multiplatform yang memungkinkan game yang anda bangun di publish untuk berbagai platform seperti Windows, Mac, Android, IOS, PS3.[7]

\subsection{Android}

Android merupakan sistem operasi yang dikeluarkan oleh Google. android dibuat khusus untuk smartphone dan tablet. Berbagai macam produsen telah menggunakan android sebagai sistem operasi untuk peranti (device) yang mereka produksi. Android juga mempunyai store dengan lebih dari 2 miliar pengguna aktif. Android software develover Kit $(S D K)$ merupakan kit yang bias digunakan oleh para develover untuk mengembangkan aplikasi berbasis android. Di dalamnya terdapat beberapa tools seperti debugger, software libraries, emulator, dokumentasi, simple code dan tutorial. Bahasa pemrograman yang digunakan untuk mengembangkan aplikasi android adalah java. Namun ada beberapa bahasa lain yang dapat digunakan, seperti C++ dan Go.[9]

\section{METODE PENELITIAN}

\subsection{Analisis Sistem}

Pada analisa system ini akan di jabarkan secara keseluruhan mengenai kebutuhan apa saja yang harus ada pada aplikasi tersebut baik secara fungsional maupun non fungsional. 


\subsection{Analisi kebutuhan}

Bertambah tua dunia teknologi semakin marak tercipta oleh manusia dengan perubahan dan perkembangan zaman. Bagaimana cara kita agar tetap bisa mengikuti perkembangan zaman ? Teknologi terus berkembang, banyak metode pembelajaaan yang digunakan untuk meningkatkan minat belajar dalam mengenalan bentuk struktur DNA manusia. Dengan aplikasi visual DNA manusia menggunakan Augmented Reality sebagai sarana media pembelajaran berbasis android bertujuan mempermudah proses belajar bentuk struktur DNA manusia dengan menampilkan objek 3D, menyisipkan suara beserta memberikan informasi teks yang telah disediakan. Hal tersebut akan memberikan wawasan bagaimana mengenal bentuk 3 dimensi.

\subsection{Analisis kebutuhan Fungsional}

Dalam pembuatan aplikasi visual DNA menggunakan Augmented Reality berbasis android membutuhkan perancangan konsep yang berguna untuk membantu dalam pembuatan aplikasi.

Tahapan ini diawali dengan mengenal dan menganalisa masalah yang bersangkutan dengan pembuatan aplikasi tersebut. Hasil analisis tersebut menghasilkan konsep aplikasi edukatif pengenalan bentuk struktur DNA manusia yang berfungsi tidak hanya sebagai media pendamping pembelajaran tetapi juga sebagai salah satu sarana ilmu pengentahuan umum. Setelah konsep terbentuk, terdapat beberapa hal yang harus dipenuhi guna pembuatan aplikasi ini. Yang pertama adalah pembuatan objek 3D struktur DNA manusia dengan menggunakan software blender. Kedua, pembuatan marker dengan memanfaatkan gambar masing-masing objek dengan format .jpg. Ketiga, menyiapkan database berisi marker yang telah dibuat yang nantinya menjadi image target saat proses scan. Keempat, membuat desain aplikasi menggunakan unity3d. Kelima, proses scan marker dan pembuatan button function pada software unity $3 \mathrm{D}$.

\subsection{Blog Diagram Sistem}

Blok diagram sistem pada aplikasi visual DNA manusia di tunjukkan pada gambar 3.1 berikut.

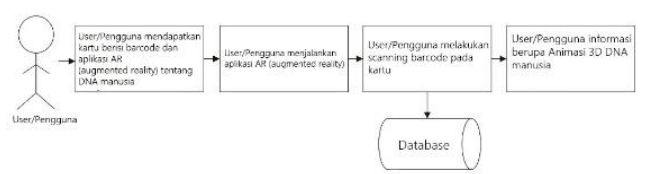

Gambar 3.1 Blog Diagram Sistem Aplikasi

Pada blok diagram system dapat diketahui langkah awal sebelum menjalankan aplikasi yaitu user mempunyai katalog yang berisi marker dan informasi mengenai aplikasi visual DNA manusia menggunakan Augmented Reality sebagai sarana media pembelajaran. Kemudian user menjalankan aplikasi dan kemudian melakukan scan, dimana marker akan di scan kemudian system akan mengambil informasi berupa objek 3D dari database.

\subsection{Use Case}

Use case ini menjelakan proses interaksi user dengan sistem Aplikasi Visual DNA Manusia Menggunakan Augmented Reality sebagai sarana media pembelajaran yang di tunjukkan pada gambar 3.2 .

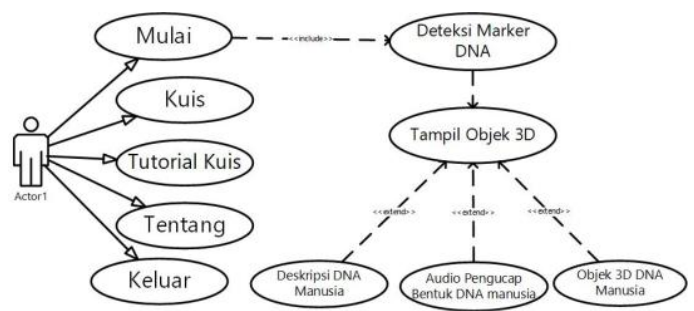

Gambar 3.2 Use Case Diagram

\subsection{Flowchart sistem}

Flowchart sistem ini menjelaskan proses berjalananya aplikasi seperti terlihat pada Gambar 3.3 berikut.

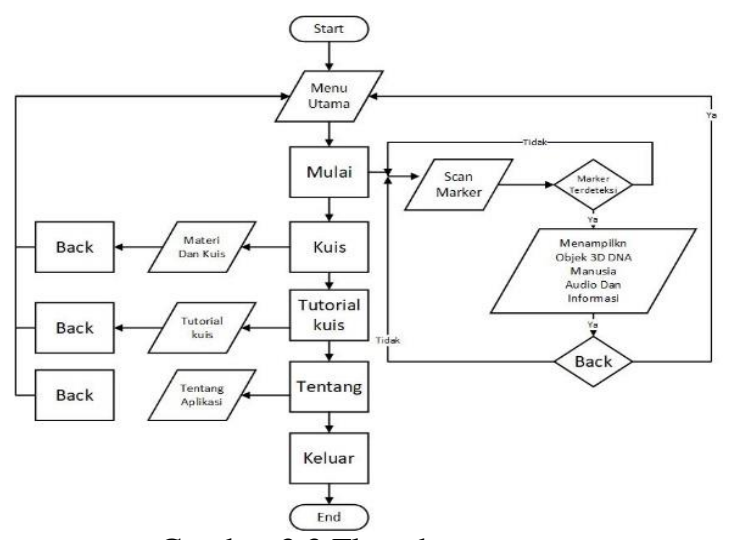

Gambar 3.3 Flowchart system

Pada flowchart sistem diatas proses mulai dari start yaitu tampilan menu utama pada aplikasi.Kemudian terdapat 4 fitur yaitu pertama halaman scan marker yang langsung terhubung dengan kamera smartphone.Setelah melakukan scan marker dan marker sesuai maka muncul objek 3D dan informasi deskripsi berupa audio dan teks.Selanjutnya kedua halaman Kuis terdapat dua pilihan yaitu materi dan kuis seputar struktur $D N A$ manusia.Selanjutnya ketiga halaman tentang yang berisikan deskripsi aplikasi dan profil developer. Dan proses berakhir apabila kita menekan tombol keluar aplikasi atau end pada Flowchart.

\subsection{Flowchart Augmented Reality}

Flowchart augmented reality ini menjelaskan proses pembacaan marker pada sistem augmented reality itu sendiri seperti pada Gambar 3.4 berikut. 


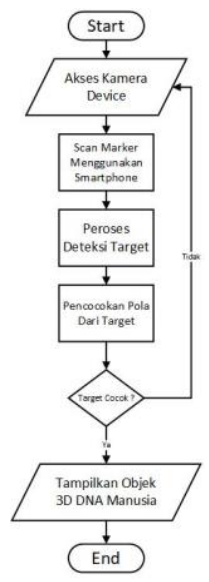

Gambar 3.4 Flowchart Augmented Reality

Proses pendeteksian marker di mulai dengan pembacaan marker oleh kamera smartphone .Kemudian kamera akan mendeteksi marker tersebut.Keakuratan deteksi pada marker tergantung beberapa hal yaitu intensitas cahaya,jarak marker dengan kamera, dan resolusi kamera.Jika marker dengan kamera tidak terdeteksi, maka pengguna harus mengatur marker dan menunjukan kembali pada kamera.Jika marker terdeteksi maka akan muncul objek 3D dan informasi sesuai dengan marker.

\section{HASIL DAN PEMBAHASAN}

\subsection{Pengujian Halaman Home}

Tampilan halaman home aplikasi berisikan 5 button yaitu button mulai, kuis, tutorial kuis, tentang dan keluar, button mulai apabila di klik akan merujuk ke scane kamera, button kuis apanila di klik akan merujuk ke halaman kuis, button tentang apabila di klik akan merujuk ke halaman tentang dan button keluar apabila di klik akan menutup aplikasi.

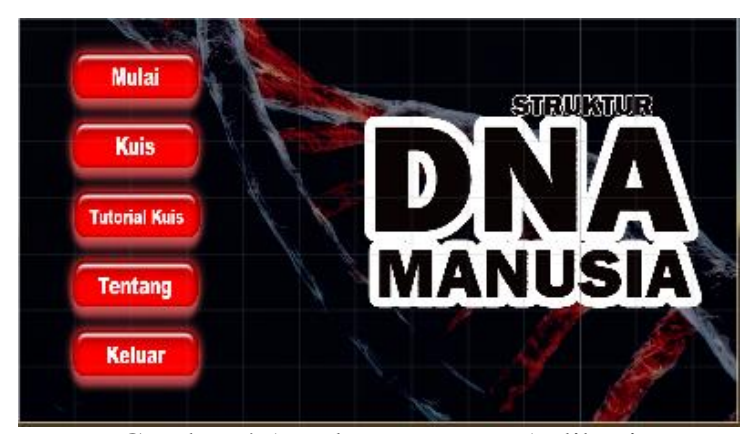

Gambar 4.1 Halaman Home Aplikasi

\subsection{Pengujian Halaman Scan Marker}

Tampilan scane marker pada aplikasi, terdapat 3 button yaitu button deskripsi suara objek, button deskripsi tek objek dan button kembali ke halaman home aplikasi.

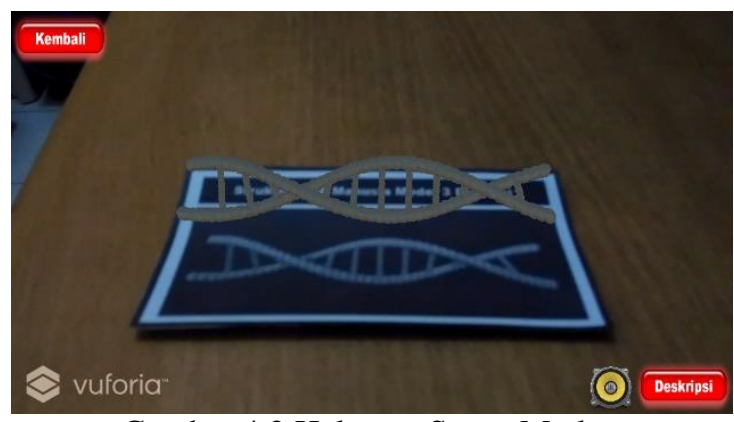

Gambar 4.2 Halaman Scane Marker

\subsection{Pengujian Halaman Kuis}

Pada halaman kuis aplikasi terdapat 3 button yaitu button materi tentang Struktur DNA manusia, button kuis berisikan soal pilihan ganda dan button kembali ke halaman home.

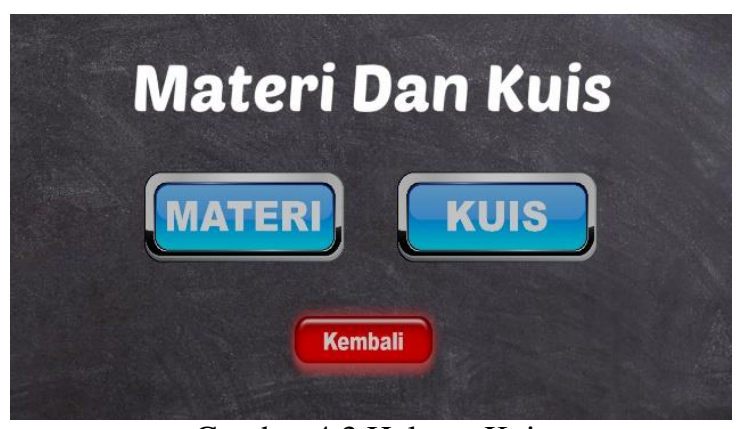

Gambar 4.3 Halama Kuis

\subsection{Pengujian Halaman Tutorial kuis}

Pada halaman tutorial kuis, berisikan informasi tentang pandual cara mengoperasikan fitur kuis, dan terdapat 1 button kembali ke halaman home aplikasi.

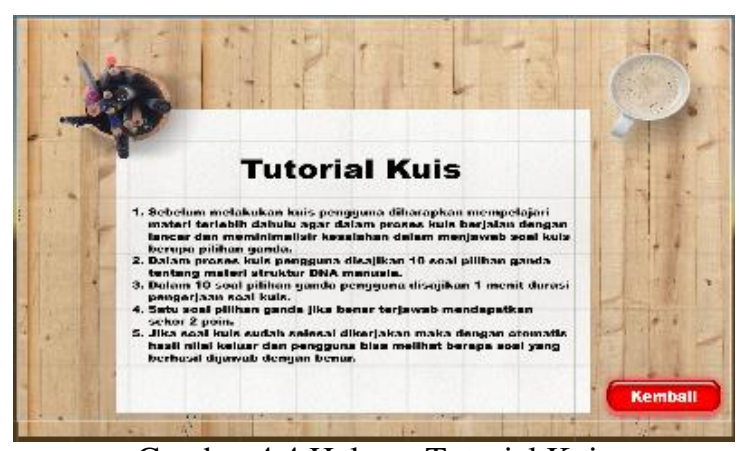

Gambar 4.4 Halama Tutorial Kuis

\subsection{Pengujian Halaman Tentang}

Pada halaman tentang, berisikan informasi tentang aplikasi dan pengembang, dan terdapat 1 button kembali ke halaman home aplikasi. 


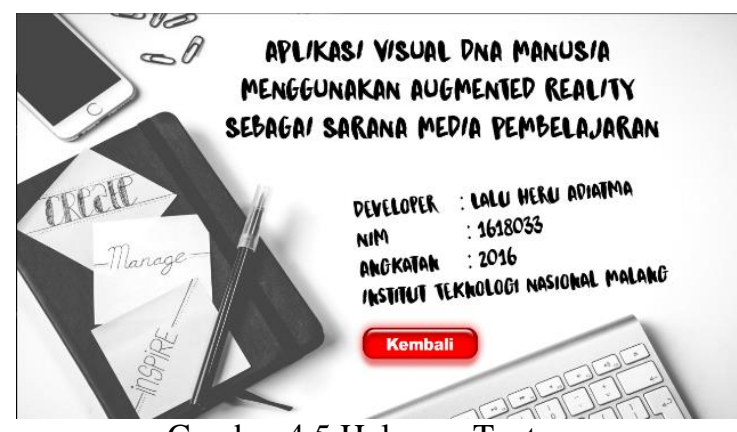

Gambar 4.5 Halaman Tentang

4.6. Tampilan Desain Marker Yang Digunakan

Contoh tampilan desain marker yang akan digunakan nantinya saat scan marker objek struktur DNA manusia.

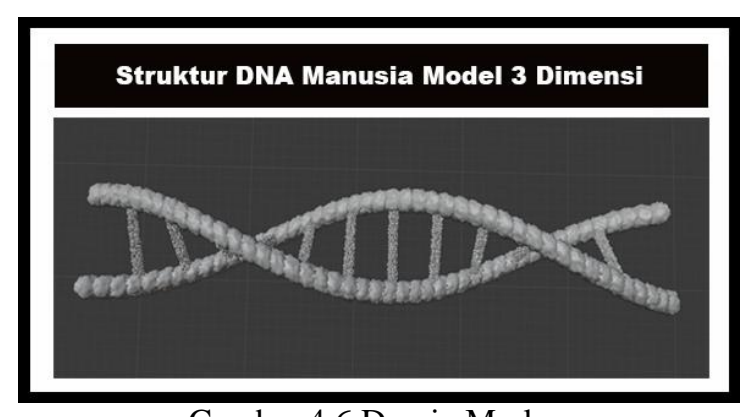

Gambar 4.6 Desain Marker

\subsection{Hasil Pengujian Pada Perangkat Android}

Halaman Pengujian perangkat dilakukan untuk mengeteahui kinerja aplikasi saat di jalankan pada smartphone. Pengujian ini di lakukan pada beberapa smartphone dengan spesifikasi berbeda. Berikut adalah hasil uji coba Aplikasi Visual DNA Manusia Menggunakan Augmented Reality Sebagai Sarana Media Pembelajaran pada beberapa perangkat pada Tabel 4.2 berikut.

Tabel 4.2 Hasil Pengujian Perangkat Android

\begin{tabular}{|l|c|c|c|c|}
\hline \multicolumn{1}{|c|}{ Merk } & $\begin{array}{c}\text { Sistem } \\
\text { operasi }\end{array}$ & RAM & $\begin{array}{c}\text { Hasil Uji Coba } \\
\text { Install }\end{array}$ & $\begin{array}{c}\text { Keteran } \\
\text { gan }\end{array}$ \\
\hline $\begin{array}{l}\text { Xiaomi } \\
\text { Redmi 2 } \\
\text { Prime }\end{array}$ & $\begin{array}{c}\text { Lolipop } \\
5.1 .1\end{array}$ & 2 GB & $\checkmark$ & $\begin{array}{c}\text { Load } \\
\text { lama 1-3 } \\
\text { detik }\end{array}$ \\
\hline $\begin{array}{l}\text { Samsung } \\
\text { A8 }\end{array}$ & Pie 9.0 & 4 GB & $\checkmark$ & $\begin{array}{c}\text { Normal } \\
1-2 \text { detik }\end{array}$ \\
\hline $\begin{array}{l}\text { Sony } \\
\text { Xperia } \\
\text { Z3 }\end{array}$ & $\begin{array}{c}\text { Marsh } \\
\text { mallow } \\
6.0 .1\end{array}$ & 3 GB & $\checkmark$ & $\begin{array}{c}\text { Normal } \\
1-2 \text { detik }\end{array}$ \\
\hline $\begin{array}{l}\text { Redmi } \\
\text { note 5 }\end{array}$ & Pie 9.0 & 3 GB & $\checkmark$ & $\begin{array}{c}\text { Normal } \\
1-2 \text { detik }\end{array}$ \\
\hline $\begin{array}{l}\text { Samsung } \\
\text { Core } \\
\text { Duos }\end{array}$ & $\begin{array}{c}\text { Jelly } \\
\text { Bean } \\
4.1 .2\end{array}$ & 1 GB & $\checkmark$ & $\begin{array}{c}\text { Load } \\
\text { lama 1- 5 } \\
\text { detik }\end{array}$ \\
\hline
\end{tabular}

\subsection{Pengujian User}

Pengujian pengguna Pengujian pada user atau kuisioner dilakukan untuk mengetahui kepuasan pengguna dalam mengimplementasikan aplikasi visual DNA manusia menggunakan augmented reality sebagai sarana media pembelajaran, respond tampilan aplikasi, respond augmented reality, dan respond kemudahan menggunakan aplikasi. Pengujian pengguna di lakukan kepada 10 orang responden. Hasil dari pengujian pengguna dapat di lihat pada tabel 4.6.

Tabel 4.6 Hasil Pengujia User

\begin{tabular}{|c|c|c|c|c|}
\hline \multirow[b]{2}{*}{ No } & \multirow[b]{2}{*}{ Pertanyaan } & \multicolumn{3}{|c|}{ Respond Pengguna } \\
\hline & & Baik & $\underset{\text { Baik }}{\text { Cukup }}$ & Kurang \\
\hline 1. & $\begin{array}{l}\text { Bagaimana } \\
\text { tampilan pada } \\
\text { aplikasi visual } \\
\text { DNA manusia? }\end{array}$ & 8 & 2 & \\
\hline 2. & $\begin{array}{l}\text { Bagaimana } \\
\text { informasi yang } \\
\text { di sampaikan } \\
\text { pada aplikasi } \\
\text { visual } D N A \\
\text { manusia? }\end{array}$ & 6 & 4 & \\
\hline 3. & $\begin{array}{l}\text { Bagaimana } \\
\text { objek yang di } \\
\text { tampilkan pada } \\
\text { aplikasi } \\
\text { aplikasi visual } \\
\text { DNA manusia? }\end{array}$ & 8 & 2 & \\
\hline 4. & $\begin{array}{l}\text { Bagaimana } \\
\text { kemudahan } \\
\text { menggunakan } \\
\text { aplikasi visual } \\
\text { DNA manusia? }\end{array}$ & 7 & 3 & \\
\hline 5. & $\begin{array}{l}\text { Bagaimana } \\
\text { kelengkapan } \\
\text { materi yang } \\
\text { disajikan? }\end{array}$ & 7 & 3 & \\
\hline & Jumlah & 36 & 14 & \\
\hline
\end{tabular}

Dari 1. Dari 10 responden di dapatkan hasil untuk poin 1 mengenai tampilan aplikasi sebanyak 8 reponden mengatakan baik dan 2 responden cukup baik. Kemudian poin 2 mengenai informasi yang di sampaikan oleh aplikasi sebanyak 6 responden mengatakan baik dan 4 responden cukup baik. Untuk poin 3 mengenai objek $3 \mathrm{D}$ yang di tampilkan sebanyak 8 responden mengatakan baik, 2 cukup baik kemudian untuk poin 4 mengenai kemudahan penggunaan aplikasi sebanyak 7 responden mengatakan baik, 3 cukup baik dan poin 5 mengenai Bagaimana materi yang disajikan?sebanyak 7 responden mengatakan baik, 3 cukup baik. Dengan total hasil 36 poin baik, 14 poin cukup baik. 


\section{KESIMPULAN DAN SARAN}

\subsection{Kesimpulan}

Setelah dilakukan pengujian pada aplikasi Aplikasi Visual DNA Manusia Menggunakan Augmented Reality Sebagai Sarana Media Pembelajaran, maka penulis mendapatkan beberapa kesimpulan sebagai berikut :

1. Marker akan terdeteksi dengan baik apabila jarak scan tidak terlalu jauh atau dekat dan dengan kondisi cahaya yang memadai

2. Marker dapat terdeteksi dan memunculkan 3D membutuhkan durasi waktu sekita1-5 detik.

3. Marker berisi objek 3D 8 Model Struktur DNA manusia dan informasi dalam bentuk audio dan teks

4. Marker dapat terdeteksi dengan baik pada rentang jarak $15 \mathrm{~cm}$ sampai $32 \mathrm{~cm}$.

5. Marker dapat terdeteksi dengan intensitas cahaya antara 9 lux sampai 67 lux.

6. Dari sudut derajat objek Marker dapat terdeteksi dengan baik pada sudut kemiringan $30^{\circ}, 60^{\circ}$, $90^{\circ}$.

\subsection{Saran}

Berdasarkan penelitian yang telah dilakukan maka penulis dapat memberikan saran -saran untuk mengembangkan selanjutnya karena penelitian masih ini terdapat banyak kekurangan,sehingga untuk penyempurnaan dapat ditambahkan :

1. Desain objek 3D yang lebih detail dan realistik serta tampilan UI agar semakin menarik bagi user.

2. Pengembangan dalam bentuk virtual reality untuk menambahkan ilmu pengetahuan umum tentang bentuk struktur DNA manusia.

3. Pengembang bisa menambahkan multi bahasa agar bisa digunakan diseluruh dunia.

4. Aplikasi menggunkan bahasa indonesia dan berjalan dengan baik saat aplikasi dijalankan.

5. Pengembang bisa melakukan Multi marker agar bisa di terapkan pada banyak marker saat scan marker secara bersamaan.

6. Aplikasi dapat dijalankan menggunakan Android dengan minimum sistem operasi Jelly Bean 5.0 dan RAM 1 GB.

7. Kondisi yang baik untuk proses scan marker disarankan pada intensitas cahaya lebih dari 8 lux karna jika kurang dari 8 lux scan marker tidak bias berfungsi dan bias dilakukan pada kapan pun dan dimana pun.

8. Pada tombol suara belum berfungsi dengan sempurna karna terkendala saat operasikan.

9. Timer pada fitur kuis belum berjalan normal saat kuis di operasikan.

\section{DAFTAR PUSTAKA}

[1] Hidayat, T., 2017. DNA MITOKONDRIA (mtDNA) SEBAGAI SALAH SATU PEMERIKSAAN ALTERNATIF UNTUK IDENTIFIKASI BAYI PADA KASUS INFANTISIDA. Jurnal Kesehatan Andalas, 6(1), pp.213-221.

[2] Haryanto, T., Anra, H. and Pratiwi, H.S., 2017. APLIKASI AUGMENTED REALITY SEBAGAI MEDIA PEMBELAJARAN MATERI PEMBELAHAN SEL DALAM MATA PELAJARAN BIOLOGI. Jurnal Sistem dan Teknologi Informasi (JUSTIN), 5(2), pp.209-212.

[3] Kristian, H., Setiawan, H. and Kelanata, O.H., 2015. Implementasi Augmented Reality Visualisasi Rumah Berbasis Unity. SMATIKA JURNAL, 5(02), pp.40-44.

[4] Dedy Irawan, J., Prasetio, S., Adi Wibowo, S. and Agus Pranoto, Y., 2015. PELATIHAN PEMBUATAN

GAME MENGGUNAKANGREENFOOT. INDUSTRI INOVATIF, 5(2), pp.29-35.

[5] Apriyanti, M.E. and Febriansyah, A., 2017, November. AUGMENTED REALITY PENGENALAN JENIS HEWAN HERBIVORA 3D MENGGUNAKAN METODE SINGLE MARKER. In Seminar Nasional Informatika (SNIf) (Vol. 1, No. 1, pp. 587-591).

[6] Pramono, H.D., 2018. Penerapan Teknologi Augmented Reality pada Game Pengenalan Hewan Berdasarkan Jenis Makanannya Berbasis Mobile. J-INTECH, 6(01), pp.166-172.

[7] Roedavan, R. (2018). Unity - Tutorial Game Engine . Bandung: Informatika Bandung.

[8] Ramdhan, K.R., Nurhasanah, Y.I. and Korio Utoro, R., 2017. Aplikasi Media Pembelajaran Tulang Manusia Menggunakan Augmented Reality (AR) Berbasis Android. Jurnal Teknik Informatika dan Sistem Informasi, 3(3).

[9] Permana, A. I. (2018). Menjadi Android Develover Expert. Bandung: PT. Presentologis.

[10] Hendratman, H. (2015). THE MAGIC OF BLENDER 3D MODELLING. Bandung: Informatika Bandung.

[11] Yuwono, T. (2009). Biologi Molekuler. Jakarta: Erlangga. 